\title{
POR UMA POÉTICA DA INTERVENÇÃO: NARRADOR E PESQUISADOR NA PRODUÇÃO DE NARRATIVAS
}

\section{TOWARDS A POETICS OF INTERVENTION: STORYTELLER AND RESEARCHER ON THE PRODUCTION OF NARRATIVES}

\author{
Felipe Grüne Ewald* \\ Ana Lúcia Liberato Tettamanzy ${ }^{* *}$
}

RESUMO: A partir do exame de perspectivas epistêmicas abertas pelas ciências sociais, postulamos formas de os Estudos Literários lidarem com a intervenção em campo, especialmente em relação à oralidade. Apresentamos nossa experiência de campo em interação com um narrador urbano e analisamos uma situação ilustrativa. Concluímos que a concepção de uma poética da intervenção possibilita o estudo das circunstâncias de produção da narrativa, elucidando a formação do espaço enunciativo, condição para a constituição da narrativa e da dimensão estética.

PALAVRAS-CHAVE: intervenção, narrativas orais, poética, enunciação, performance.

ABSTRACT: This article begins by discussing epistemic perspectives opened up by the social sciences. We raise the possibility for literary studies to deal with forms of intervention allied with field work, especially the study of orality. We describe our experience in interacting with an urban storyteller and analyze a particular situation. We conclude that such a poetics of intervention makes possible the study of the narrative circumstances, clarifying the formation of an enunciative space, which is the condition for the production of the narrative and the aesthetic dimension.

KEYWORDS: intervention - oral narratives - poetics - enunciation - performance

\footnotetext{
Universidade Federal do Rio Grande do Sul (UFRGS) - Mestrando em Estudos Literários. E-mail: felipe.ewald@gmail.com

${ }^{* *}$ Universidade Federal do Rio Grande do Sul (UFRGS) - Doutora em Letras e Docente do PPGLET-UFRGS. Coordena o projeto A vida reinventada: pressupostos teóricos para análise e criação de acervo de narrativas orais, que recebe apoio financeiro do Conselho Nacional de Desenvolvimento Científico e Tecnológico (CNPq). E-mail: atettamanzy@terra.com.br
} 

"Morar dentro do tema é complicado."

Férrez

(escritor, morador da periferia paulista e autor de obras como Manual prático do ódio e Capão Redondo)

\section{INTRODUÇÃO}

Na proposta deste texto, está implicada a construção das narrativas orais registradas a partir do trabalho de campo como objeto de conhecimento para os Estudos Literários. No decorrer do texto apresentaremos nossa experiência de interação com um narrador urbano, analisando as condições de produção de uma poética proveniente da oralidade. Mas, antes, desejamos explorar como, em áreas afins, as perspectivas populares, ou ainda desvinculadas da centralidade da tradição escrita, vêm sendo tratadas.

\section{POR UMA POÉTICA DA INTERVENÇÃO OU DE COMO OS ESTUDOS LITERÁRIOS (NÃO) TRATAM DAS ORALIDADES}

Queremos tomar como ponto de partida as incursões que o campo das ciências sociais e humanas têm feito em relação a suas exterioridades (no caso, com os sujeitos e grupos sociais envolvidos em suas práticas). Quando se trata de abordagens a respeito das produções simbólicas de sujeitos ou grupos e do exame dos organismos sociais, o terreno é consideravelmente mais complexo - posto que suscetível de subjetivações e ambiguidades - do que nas pesquisas da área médica, por exemplo, em que os experimentos com seres humanos os transformam em objeto, ainda que respaldadas por 
comitês de ética, dedicados a monitorar as ações nas instituições. Parte dessa dificuldade, para alguns, é explicada pelo funcionamento do discurso, simultaneamente resultado e fonte de coerções e sujeições: "a doutrina liga os indivíduos a certos tipos de enunciação e lhes proíbe, conseqüentemente, todos os outros" (FOUCAULT, 2006: 43).

As academias são, nessa perspectiva, lugares de fala autorizada, que usualmente deslegitimam ou, na melhor das hipóteses, ignoram aquilo que lhes é exterior, impertinente em sua alteridade. Por essa razão, custa-lhes reconhecer que "não há apenas conhecimentos muito diversos no mundo sobre a matéria, a vida e a sociedade; há também muitas e muito diversas concepções sobre o que conta como conhecimento e os critérios de sua validade" (SANTOS, 2006: 144). Para dar conta da diversidade epistêmica do mundo (e inserir nele uma polifonia discursiva), Boaventura de Souza Santos sugere a perspectiva de intervenção: "O próprio ato de conhecer, como não cansaram de nos lembrar os filósofos ligados ao pragmatismo, é uma intervenção sobre o mundo, que nos coloca neste e aumenta sua heterogeneidade." (Ibidem: 148, grifos nossos). Vejamos, então, que atitudes adotam algumas áreas afins aos Estudos Literários diante deste desafio epistêmico.

A Antropologia nasce da necessidade de dar a conhecer os outros mundos e outros povos que o imperialismo - mas também a curiosidade humana - impôs como realidade. Se nos primórdios o outro a ser observado estava distante, em espaços "exóticos", cada vez mais a relação com o outro se estabelece num grau de maior proximidade a ponto de tornarse improvável o não envolvimento entre os participantes do processo. Contudo, ainda que permaneça difícil ao antropólogo defrontar-se com os riscos da subjetividade, novas epistemes vão surgindo, como a proposta a partir de um encontro de cientistas sociais em 2004. Inconformados com as fronteiras acadêmicas, que insistem em pensar vida e arte como polos que se excluem, debatem a dimensão poética das ciências sociais contra $o$ esquecimento da imagem e do imaginar:

Nosso compromisso é ético nos processos sociais que não nos pertencem, mas dos quais podemos participar tomando a palavra [...] Um modo de nos implicarmos com a imagem, o imaginário, o sonho e a esperança de continuar instigando o conhecimento, desfazendo representações definitivas e ousando durar na incerteza e na descontinuidade (MARTINS; ECKERT; NOVAES, 2005: 10). 
Na História, a partir do século XX e da crítica à perspectiva positivista, novos atores e teorias propõem formas de dar conta dos rastros do passado. No limite entre a interpretação dos fatos e a busca pela verdade científica, a proposta da história cultural acarreta controvérsias como a construção da memória e a representação do mundo, a qual é, "ela também, parte constituinte da realidade, podendo assumir uma força maior para a existência que o real concreto" (PESAVENTO, 1999: 8). Segundo essa perspectiva, o historiador imagina o passado, que é reconstruído em sua narrativa e, por sua vez, constitui uma representação do real. A partir do presente, o historiador busca compreender os sistemas de ideias e imagens de homens de outras épocas - e tanto ele como os narradores do passado produzem representações. Naturalmente, a imaginação contribui para essa reconstrução do passado.

Da mesma forma, para os que trabalham com história oral, é sabido que os relatos sobre o passado comportam a "experiência subjetiva [...] fatos pinçados aqui e ali nas histórias de vida dão ensejo a percepções de como um modo de entender o passado é construído, processado e integrado à vida de uma pessoa" (CRUIKSHANK, 2001: 156).

Para a literatura assombra um mal-estar, desde a constatação sobre seu sem-sentido, inutilidade ou crise até o desconforto com manifestações brutas, hiper-realistas de representações recentes por parte de autores excêntricos (porque originários de estratos menos favorecidos da sociedade) ou diaspóricos (como entende Stuart Hall ${ }^{1}$ ).

Roland Barthes (1992: 17), sob a premissa de que o poder que sujeita a todos é a língua, define a literatura como uma forma de trapaceá-la: "as forças de liberdade que residem na literatura não dependem da pessoa civil, do engajamento político do escritor que, afinal, é apenas um 'senhor' entre outros, nem mesmo do conteúdo doutrinal de sua obra, mas do trabalho de deslocamento que ele exerce sobre a língua". No mesmo sentido, propõe que a literatura não está destruída, apenas foi retirada de seu lugar sacralizado de modelo do espírito humano. A forma para tratar a literatura como livre de tal herança converge, a seu ver, para a tomada da linguagem como objeto. Da mesma forma, entende que seria possível ensinar - ou manter

\footnotetext{
${ }^{1} \mathrm{Na}$ obra Da diáspora, o teórico dos Estudos Culturais analisa as intercorrências nas identidades multiculturais causadas pelos processos de globalização e pós-colonialismo. Uma delas diz respeito às experiências diaspóricas dos sujeitos deslocados de sua terra de origem e forçados a estabelecer novas relações de pertencimento.
} 
um discurso - sem imposições: "o que pode ser opressivo num ensino não é finalmente o saber ou a cultura que ele veicula, são as formas discursivas através das quais ele é proposto" (Ibidem: 43). Como Foucault, mencionado anteriormente, Barthes centra sua perspectiva na relevância do fenômeno da linguagem.

No entanto, forma e conteúdo não podem ser facilmente dissociados. Frente ao já longo dilema se a vida imita a arte ou o inverso, ou, dito de outro modo, se a literatura possui qualquer relação com o mundo, Todorov (2009: 77) entende que o leitor comum, que busca "nas obras que lê aquilo que pode dar sentido à sua vida, tem razão contra professores, críticos e escritores que lhe dizem que a literatura só fala de si mesma ou que apenas pode ensinar o desespero".

Nesse sentido que a proposta de examinar a poética das narrativas orais pode ser uma alternativa para um suposto esgotamento do literário em meio a niilismos, egotismos e irracionalismos pós-modernos. Por um lado, os estudos das ditas "literaturas tradicionais" concentravam-seem comunidades mais ou menos estabelecidas, normalmente em espaços circunscritos "rústicos", rurais, não-urbanos -, dando conta de manifestações ancestrais e ancoradas em relação com espaços naturais marcantes. Nesses casos, o anonimato, a ancestralidade, o vínculo comunitário eram imprescindíveis na constituição dos relatos. Por outro lado, nas grandes cidades, as condições da cena enunciativa são consideravelmente diversas. Os vínculos com a paisagem ou com o passado enfraquecem - que tradição é possível imaginar para as metrópoles? Talvez por isso mesmo, surgem outras perspectivas.

As táticas de bricolagem do sujeito que caminha pela cidade originam uma fala nômade, que incorpora a impureza e a errância em seu discurso: "caminhar é ter falta de lugar" (CERTEAU, 1994: 183). Esse sujeito desenvolve astúcias que lhe permitem burlar a tradição escriturística no sentido de formular originais apropriações do espaço e da cultura. Uma das tendências mais evidentes nessa direção é a escrita que surge das periferias e dos presídios das grandes cidades, por parte de "excluídos" que não querem mais mediadores nem intermediários:

O que procuram, ao desejar fazer literatura, é levar tal realidade para a ágora, para o espaço de discussão de intelectuais (que mereçam esta qualificação), editores, políticos, público, enfim, mas levar por suas próprias mãos. É dessa maneira que ocupam a polis e criam uma nova forma de literatura assumidamente política. Desse modo, diante de nossa perplexidade, torna-se evidente que é somente nessa cidade politizada que a realidade pode deixar espaço para imaginários em liberdade (RESENDE, 2008: 39-40). 
A proposta aqui converge também para a cidade, mas propõe que a universidade experiencie a falta de lugar e caminhe na direção de um espaço de diálogo com as comunidades. "O trânsito entre os diferentes mundos, planos e províncias é possível graças à natureza simbólica da construção social da realidade." (VELHO, 1999: 29). Não basta tratar das oralidades tomando como base os registros que outros fizeram, seja como compiladores de versões orais de narrativas tradicionais, seja como criadores de literatura publicados e, como tal, submetidos à lógica do mercado editorial e do livro impresso. Tem-se que praticar a errância e optar por uma longa e vertiginosa experiência de campo. Da atitude de escuta paciente, sem metodologias restritivas, constrói-se uma relação com narradores de espaços urbanos, em seus lugares de convivência (privada ou social), da qual resultam suas performances. Importa analisar a qualidade dessa poética da voz, indissociável das suas condições de produção e recepção. Importa ainda operar numa lógica de disseminação dessas criações, oportunizada em redes na comunidade ou em espaços virtuais, para que os autores compartilhem suas histórias com seus próximos.

Ao levar tal produção para a universidade, a opção é pelo tensionamento do cânone e das instâncias de valor costumeiramente autorizadas a institucionalizar o literário. Esse enfrentamento é potencializado nos espaços urbanos pelo que Milton Santos (2008: 74) chama de flexibilidade tropical: lugar da diversidade de classes sociais, das diferenças de renda e dos modelos culturais, as cidades são "dotadas de flexibilidade, graças a um meio ambiente construído que permite a atuação de todos os tipos de capital e, desse modo, admite a presença de todos os tipos de trabalho". As periferias, segundo essa concepção, aparecem como zonas de resistência em que os tempos rápidos da hegemonia global são subvertidos por um tempo lento e opaco que permite outras condições de sobrevivência. A partir desse lugar é enunciada uma postura particular sobre o conhecimento, no sentido de propor objetos diferentes para o exame acadêmico através do que chamamos aqui de uma poética de intervenção.

\section{A INTERAÇÃO EM CAMPO COMO PRODUTORA DAS NARRATIVAS}

Diante deste diagnóstico da necessidade de se abordar a produção proveniente de espaços urbanos periféricos, passaremos a relatar a experiência de campo que construímos sob o enfoque de intervenção apresentado na primeira parte. 
O trabalho de campo ocorre na Restinga - bairro da periferia de Porto Alegre, Brasil -, formada a partir da remoção de populações do centro da cidade, desde a década de 1960. Ele se dá através do contato com um morador específico, que chamaremos aqui apenas por Beleza, o qual congrega alguns vizinhos para conversas em encontros que se dão, na maior parte das vezes, em sua casa. Suas narrativas são o ponto de referência da discussão a ser travada aqui. Nosso objetivo com este trabalho é observar e compreender as circunstâncias de produção das narrativas orais do referido narrador. Enfocamos o funcionamento do discurso, captado a partir da comunicação oral, de uma situação de performance ${ }^{2}$, como o objeto proveniente de uma poética.

O que buscamos é a voz poética de um narrador, não é a voz da comunidade, ou a voz do cantador responsável pela memória de seu povo, não é a representação de uma sociedade (FONSECA, 1999). O que está em questão é a produção de uma individualidade, que, certamente, também carrega elementos sociais, constitutivos de sua comunidade.

Não utilizamos um método de condução ou entrevista dirigida, nem mesmo um roteiro aberto. Buscamos a conversa cotidiana desestruturada e des-hierarquizada - o tanto quanto isto é possível -, mas que vem permeada de intenções de códigos prévios, de conhecimento preliminar de um suposto objetivo com as conversas que mantemos. O Beleza tem uma demanda que o impele a nos receber: ele deseja que os conhecimentos estruturados pela memória nas narrativas sejam compartilhados, com o objetivo de alcançar uma articulação da comunidade. É nesta reciprocidade voltada à ação que se entrecruzam nossas atitudes intervencionistas.

Não observamos uma interação comunitária que ocorra independente de nós, pesquisadores. Pelo contrário, provocamos as performances, intervimos no ambiente. As histórias são contadas para os vizinhos e companheiros da comunidade e igualmente para nós. Nossa escuta constante também dispara as narrativas. O diálogo, a partir de um contato semanal,

\footnotetext{
${ }^{2}$ Conceito essencial para Zumthor $(1997,2005)$, a performance sugere a ação comunicativa complexa em que uma mensagem poética é simultaneamente, aqui e agora, transmitida e percebida. Encontram-se presentes locutor, ouvinte e circunstâncias, que se confrontam concretamente. Assim, ocorre uma reciprocidade de relações entre eles, o que provoca a interação de cada um desses três elementos com os outros dois. A abertura conferida à poesia oral por seu traço movente permite a recriação de um saber, questionado incessantemente, em que cada performance instaura uma nova integridade.
} 
prolongado e sistemático, que já dura mais de dois anos, tem tonalidades cotidianas. Além disso, está em jogo o fato de, em algumas ocasiões, estarmos filmando, o que gera uma mediação e amplifica o alcance e a distribuição das narrativas entre os membros da comunidade.

Conquergood (2004) defende que o conhecimento deve ser construído em solidariedade com - e não em separação das - pessoas. Em nossa experiência de campo, compartilhamos a produção de conhecimentos com vistas a uma intervenção. Assim, produz-se um tensionamento dos limiares entre a maneira como a teoria age sobre a prática e o que a prática propõe à teoria. Delineamos algumas atitudes possíveis: adequar o trabalho ao mundo, ao invés do contrário; conhecer os hábitos e práticas realizados no mundo, ao invés de ter a pretensão de determiná-los, buscando a imposição de categorias analíticas acadêmicas; buscar e reconhecer a produção realizada, ao invés de recebê-la pela mediação do mercado editorial; assumir a produção do objeto também por parte do pesquisador.

A construção das narrativas será, portanto, abordada a partir da discussão acerca da constituição do corpus e dos fatos a serem analisados. Vemo-nos obrigados a estabelecer a materialidade sobre a qual realizamos o estudo, como ela é construída e de que forma pode ser compartilhada com nossos leitores, uma vez que se trata aqui de uma experiência de campo com narrativas orais inserida em um trabalho acadêmico de divulgação científica.

"A produção de uma obra de arte é a delimitação de uma matéria, modelizada, provida de um começo, de um fim, animada de uma intenção, pelo menos latente" (ZUMTHOR, 1997: 81). Na produção oral há uma rarefação desta matéria, diferente do sistema editorial ligado à escrita, em que há sistemáticas de suporte, duração e distribuição. O processo ligado às narrativas orais é, primeiramente, dependente da sensibilidade, do corpo, da memória, do receptor, do domínio da linguagem compartilhada, do fundo dialógico desta linguagem. "A forma 'pura' da obra poética oral é o que, da dimensão dada a seu espaço pelo gesto, subsiste em memória, depois que as palavras foram suprimidas. Tal é a experiência estética que constitui a performance." (Ibidem: 216)

Podemos, então, pensar em usar o recurso audiovisual como meio de inscrição das narrativas orais. Certamente, o vídeo é alentador para a ânsia do pesquisador que procura tudo registrar. Ele também auxilia na retomada dos discursos para fins de análise. No entanto, em nossos vídeos não se encontra a completude das situações narrativas, já que a totalidade da 
performance depende da ambiência, da ocasião, dos diferentes elementos, dos estados de humor, do presente que aquela enunciação ${ }^{3}$ estabeleceu e é único e irrepetível.

A partir de um ponto de vista radical, centrado no polo de recepção, temos que, nas narrativas orais, é sempre, pelo menos, o sujeito-receptor quem a propõe. Esta postura extrema ilustra o inevitável processo de construção dos objetos a serem analisados.

Assim, qualquer pesquisador que estude a produção oral será um receptor e definirá, ele também, o todo do enunciado narrativo. Em sua transcrição ou vídeo, ditará o esquadrinhamento da narrativa e, provavelmente, deixará de fora alguns elementos que a integram, por seu conhecimento incompleto do gênero. Afinal, as marcas de início e fim não se limitam às fórmulas consolidadas pelas histórias escritas, como 'era uma vez' e 'foram felizes para sempre'.

Sob a perspectiva dialógica de Bakhtin (1992: 325), "ter um destinatário, dirigir-se a alguém, é uma particularidade constitutiva do enunciado, sem a qual não há, e não poderia haver, enunciado". A orientação do discurso ajustado ao receptor justifica nossa ênfase ao papel da recepção no que tange à produção das narrativas.

No ato de audição de uma comunicação oral, os polos de emissão e recepção estão unidos. No entanto, este é um evento enunciativo, singular e irrepetível. As formas de retomar esta comunicação ocasionarão novas instâncias de enunciação, ou seja, outras condições de sujeito, espaço e tempo. A mediação do vídeo ou da transcrição explicita a condição produtiva compartilhada por narrador e pesquisador, o qual opera a seleção do discurso daquele.

Com a transcrição, a poética oral passa à dimensão escrita nos momentos de cristalização dos relatos de pesquisa como o presente, quando ocorre a reconstrução e rematerialização da narrativa, que já percorreu a espacialização vocal, a mediação do audiovisual, até chegar ao meio

\footnotetext{
${ }^{3}$ Benveniste $(1991,1995)$ concebe a língua como um sistema que comporta nela mesma a capacidade de se atualizar, através de mecanismos específicos. Ela congrega, simultaneamente, a estrutura e o acontecimento, a regularidade e a singularidade e, por isso, é um conceito, a um só tempo, universal e particular. "A enunciação é este colocar em funcionamento a língua por um ato individual de utilização." (BENVENISTE, 1991: 82) É o ato mesmo de produzir um enunciado. Seu estudo se dá pelas marcas deixadas no enunciado. Dito de outra forma, pela procura de marcas do ato irrepetível nos produtos deixados pelo processo.
} 
escriturístico. Ela não é, de forma alguma, neutra, mas se configura como um novo ato de enunciação, efêmero e singular, por parte do pesquisador.

A enunciação é um ato que não pode ser visto desvinculadamente do sujeito que a produz, [então] a transcrição é um ato de enunciação em que o "dado" a ser transcrito tem seu estatuto enunciativo alterado. A transcrição é, por esse viés, uma enunciação sobre outra enunciação (FLORES, 2006b: 62).

A transcrição possui um duplo estatuto: ela mostra algo, dizendo outra coisa. É da ordem do mostrar, a transcrição da cena, a alusão a uma situação que se tenta remontar. Pela ordem do dizer, a transcrição conforma-se como uma outra enunciação. $\mathrm{O}$ valor da operação de ciframento - a forma do mostrar - não é absoluto, mas relativo ao que tenta transcrever, ainda que, em geral, se tente ignorar o impossível da passagem de um sistema a outro. A operação de deciframento - própria do dizer - pressupõe a leitura do transcrito, do mostrado, instância em que estará passando a dizer o que mostra. Esta operação supõe uma pretensa totalidade, de que se leia exatamente aquilo que, ao transcrever, quis-se mostrar, nem mais, nem menos (Ibidem).

A organização singular da narrativa elaborada pelo Beleza é o fato enunciativo reelaborado pelo modo de observação e seleção aplicado por nós, pesquisadores. É, portanto, produto de um gesto de interpretação específico.

Antes de passar à transcrição de uma narrativa particular devemos considerar as diferentes proporções tomadas pelo corpus: há mais de dois anos presenciamos as situações narrativas em campo, em interação com o Beleza. Destas, apenas algumas estão registradas em vídeo. Para fins deste artigo, reconstituiremos somente um pequeno trecho de um dos encontros filmados. É uma escolha de certa forma aleatória de um fato narrativo, diante da impossibilidade e mesmo incoerência que seria tentar expor a vastidão do corpus, uma vez que nosso objetivo é observar as estratégias narrativas, não conteúdos.

Em lingüística da enunciação o dado não é jamais "dado", mas se configura num fato na medida em que é produto de um ponto de vista, o que cria o objeto a ser analisado. Os dados [fatos?], ao serem apresentados com recortes [...], possibilitam que se enfoque mais detidamente a cena enunciativa (FLORES, 2006a: 116). 
A análise do caso particular, através da perspectiva enunciativa, nos possibilita apreender os princípios de organização das narrativas, que são atualizados a cada enunciação, concretizados em discurso na performance, a face visível e fugidia, a qual apenas rende elementos para captar o real objeto que existe em potência. Este é um modelo teórico para as narrativas do Beleza, as quais estão, elas mesmas, imbuídas da vontade de intervir. É uma ética da intervenção que aprendemos com as práticas do narrador e os conhecimentos articulados em sua narrativa. Vejamos o fato que selecionamos abaixo ${ }^{4}$ :

BELEZA: Nós temos que estimular as pessoas a ter defesa, a saber se defender, né. Ah, pois é, lá tem um bando de tarado [...] a mulher fica sabendo disso, ela nem passa por perto, né. $\mathrm{O}$ trabalho/não tem que falar isso pras crianças, não tem que estimular ela a ter medo. Tem que estimular ela a ter defesa. Bom, se acontecer isso, o que que tu tem que fazer: tu tem que ir pra casa da vó, tu tem que ir pra casa não sei de quem, pra quem tu confia, tu sabe que não vão fazer maldade contigo. Então, ó, bota o pé na estrada. Depois, não te esquece. Tem um telefone aqui, liga pra quem tu achar, liga pra polícia, liga pra brigada, pra quem tu quiser. Agora, não fica no marasmo...

ALESSANDRA ${ }^{5}$ : achar que isso é normal, né.

BELEZA: isso, achar que isso é normal, que isso é/não, porque, né, o cara é adulto vai te/não, não é assim. Então, muitas vezes os colegas lá ficavam brabo comigo, né, na época que eu trabalhava lá no conselho [tutelar de Porto Alegre]. Porque vamos fazer não sei o que, porque tem que denunciar. Não adianta, cara, a justiça não é do nosso meio, a justiça é de outro meio. Eles vão preservar o bem deles, o que interessa pra eles. Ah, tu mora lá na Restinga, então vai continuar sendo abusado, vai continuar tomando tapa nos [...] do teu marido lá, porque tu não faz nada, né. [início] Eu/chegou vez aqui de ter/a mulher: o que que eu faço Beleza, o cara é um sem-vergonha, não sei o que, faz isso, bebe não sei o que. Querida, panela tem asa pra quê? Passa a mão numa asa

\footnotetext{
${ }^{4}$ Vich e Zavala (2004) lembram que a representação pela escrita tende a se forçar a propor coerências. A narração oral, no entanto, é altamente fragmentária e em geral construída sobre a base do diálogo, em uma estrutura conversacional, participativa do contexto de conversação. Por isso, a transcrição procura manter a estrutura de diálogo e os trechos aparentemente incoerentes, já que a construção dos sentidos provém da totalidade da performance, requer a presença do corpo, do olhar, da entonação, instâncias ausentes na escrita.

${ }^{5}$ Alessandra Flach é integrante do grupo de pesquisa da universidade.
} 
duma panela e finca nas guampas desse filha-da-puta. Bah, sabe o que que a mulher fez? A mulher botou fogo no cara, botou álcool. Claro, ele foi/morreu depois, né. Aí ela descobriu que ele tinha AIDS. Aí, ela foi descobrir que ela tinha AIDS, que as filhas tinham AIDS, porque ele transmitiu pras filhas. Mas eu fiquei/eu acabei/ o juiz lá me disse assim: pô Beleza, conselho [...], mas não precisava tanto né, pô, a mulher botou fogo no cara. Digo: ah, mas não fui eu, não fiz nada disso daí.

ANA: era tanta raiva...

BELEZA: era tanta raiva, mas ela ficou tão danada, tão/porque ela sempre dizia/chegava lá com um olho pra fora: olha aí, o que que eu faço?, fui lá na delegacia, o cara ficou rindo da minha cara... Lá pela décima vez, eu disse: olha minha querida, só vou falar uma coisa: panela tem um monte de asa pra quê?, pra isso, pra segurar e fincar [...] do cara, né?

ANA: mas ele abusava das filhas também?

BELEZA: ele abusava das filhas. Era um horror, tem que ver, e o cara era o maior debochado ainda. O pior de tudo era que tinha que ouvir ele, eu tinha que ter estômago frio pra ouvir o desgraçado, ainda, ouvir a conversa dele, né. Porque, afinal de contas, ele era um cidadão, eu tinha que garantir o direito dele ser ouvido, né, eu tinha que garantir isso, mas a minha vontade era de/eu tinha uma colega que começava a gritar na frente dele e a ofender ele. Aí eu pegava e tirava ele, botava numa sala só comigo: não, deixa lá que eu vou pelo menos poder/ele vai ter que ter a garantia de ser ouvido, ele tinha que ser ouvido.

ANA: e o que que ele dizia?

BELEZA: ah, ele dizia que era papo, não sei o que, que ele não fazia, que só tomava uns goles, que isso aí não tinha nada a ver, que na verdade era o jeito dele se relacionar com ela, que ela é que não entendia. Eu chegava e dizia: olha isso daqui, tá aqui os exames rapaz, a mulher com os olhos tudo roxo, um caroço em cima do olho, porque ele deu de soco na cabeça da mulher. Não, não é, não sei o que, isso aí ela é que bateu no canto da mesa lá, não sei o que. Ele dava um monte de desculpas. Era uma cara de pau. [final] Porque é aquele negócio: nós, de novo, voltamos praquela questão inicial, nós não estimulamos as criaturas a ter autocrítica das coisas (Registro Audiovisual, 11 de outubro de $\left.2007,24^{\prime}\right){ }^{6}$

\footnotetext{
${ }^{6}$ Queremos esclarecer aqui alguns critérios para a transcrição. Utilizamos a norma culta da língua com algumas exceções, a fim de, em primeiro lugar, lembrar da incompletude e das forçosas escolhas que esta tradução entre diferentes sistemas impõe; em segundo lugar, manter alguns traços que nos lembrem que estes textos são falas: para a segunda pessoa
} 
Para delimitar e construir esta narrativa, valemo-nos de nossa longa experiência de escuta do Beleza, o que nos possibilita delinear uma espécie de ontologia da sua prática poética, definindo princípios de existência, surgimento e organização da narrativa em performance. São narrativas inseridas no fluxo da ação social, dentro do universo cotidiano. Elas não são peças autônomas: no fio do discurso, há elementos que as precedem e sucedem, criando enquadres de referência. Na história citada, de conteúdo bastante contundente e trágico, como é característico no meio urbano, o engate acontece em função da conversa, no contexto do Conselho Tutelar, sobre como educar as crianças para ter autonomia e agir em casos de violência. Assim, verificamos que no discurso do Beleza está presente uma lógica argumentativa, em que o dado debatido é aplicado em um caso exemplar, defendendo o que ele pensa ser possível fazer para contornar as dificuldades. No ato enunciativo da narrativa, a identificação entre narrador e ouvinte se dá pela forma estética.

Certeau (2005), lançando o olhar sobre as maneiras de falar, lembra que a retórica opera pela razão em relação com a ação e o instante, como uma lógica articulada em cima da ocasião e da vontade do outro. A narrativa do Beleza se dá a partir de uma lógica dos jogos de ações relativos a tipos de circunstâncias. Nesta poética ligada à vida cotidiana, a memória se revela no momento oportuno, na ocasião. A narrativa existe em pontos de condensamento no fluxo das práticas cotidianas. Perscrutamos estas práticas através da interação com o Beleza, buscando as lógicas de quando e como uma história se encaixa. Isto ocorre toda vez que a conversa trivial provocada por nossa interação é readequada a um novo espaço pela postura enunciativa do Beleza, que reordena a situação e se coloca como aquele que vai narrar.

Em sua narrativa, há uma tensão constante entre informar e narrar. Ele discute o mundo entre o comentário e a narrativa, a qual é justamente o exercício de imaginar mundos como soluções para os problemas

do singular utilizamos a conjugação da terceira pessoa, uso coloquial natural em Porto Alegre; o verbo estar, quando conjugado, tem o es inicial suprimido. A fala do Beleza é bem "amontoada", por isso, criamos algumas convenções: a barra separa duas palavras amontoadas, geralmente sem a conclusão da primeira; as frases acompanham o ritmo corrido do Beleza, havendo poucos pontos finais e muitas vírgulas; as reticências indicam uma hesitação ou uma respiração maior; os dois pontos tentam indicar um discurso citado, sempre que possível. 
diagnosticados. Assim, ele entra e sai da história, dos personagens, provocando encaixes constantes, na tensão para dentro e para fora da narrativa. Na transcrição acima, intervimos com diferentes formas de delimitação: formamos o enquadre em meio ao fluxo discursivo, estabelecemos o recorte entre a primeira e a última palavras a serem (re)produzidas e inserimos indicações de início e fim da narrativa. O início se dá no encadeamento do enquadre de referência, de tom informativo, que precede a narrativa, a qual se configura como caso exemplar, em meio à argumentação. $\mathrm{O}$ final é discreto e se marca principalmente pelo retorno à informação, mas também, na situação de performance, pela leve mudança de ritmo. Claramente, a narrativa "Panela tem asa pra quê?" - que é recriada por ele, sob os mesmos princípios ontológicos, em, pelo menos, outros quatro momentos diferentes que temos registrados - está circundada por um tom mais didático e informativo. Ao final, fica bem amarrada a história com o debate, na clareza do método argumentativo.

A ficcionalização se evidencia na narrativa diante do contraste entre o herói épico narrado - soberano na busca de soluções e no enfrentamento dos problemas - e o narrador no mundo, que enfrenta dificuldades para alcançar a articulação social almejada. Ainda assim - e talvez por isso mesmo - o narrar está diretamente conectado com as demandas sociais urgentes da comunidade - no caso apresentado, a vulnerabilidade das crianças.

Beleza atua no mundo inserindo intensamente as práticas artísticas e operações poéticas nos domínios da vida cotidiana com a intenção de torná-los politizáveis. As dimensões ética e estética ficam indissociáveis. A conduta ética não é prescritiva apenas no conteúdo da narrativa, mas também no próprio ato narrativo. Este é um ato performativo, através do qual ele dramatiza e socializa as situações, colocando na interação os conhecimentos articulados na narrativa, com o intuito de intervir junto aos membros de sua comunidade, buscando a transformação dos problemas.

\section{CONCLUSÃO}

O horizonte da intervenção é mantido em perspectiva em todos os níveis da pesquisa, considerando que o fato narrativo recriado na transcrição não se configura apenas em objeto a ser estudado, mas é ele mesmo um saberdizer, um conhecimento que se transfere para o universo acadêmico. Beleza narra suas práticas e, assim, também age. 
Através de nós, pesquisadores, que provocamos seu poder de narrar e nos propomos a uma intervenção e um agir conjunto, o Beleza visa a projetar socialmente suas narrativas. A completude do projeto ético-estético que ele concebe a partir de seu narrar depende, também, de ter os pesquisadores como seus parceiros.

A concepção de uma poética da intervenção torna possível o estudo das circunstâncias de produção da narrativa, o qual proporciona a compreensão de como se forma o espaço enunciativo, que é condição para a constituição da narrativa e da dimensão estética. O Beleza se constitui em narrador e estabelece o espaço enunciativo a partir da ritualização da situação cotidiana, no tensionamento entre informar e narrar, através da intencionalidade e ficcionalização, envolvendo em seu discurso, constitutiva e explicitamente, seus interlocutores, o que produz uma unidade poética.

\section{REFERÊNCIAS BIBLIOGRÁFICAS}

BAKHTIN, Mikhail. Os gêneros do discurso. In: BAKHTIN, Mikhail. Estética da criação verbal. Trad. Maria Ermantina Galvão Gomes Pereira. São Paulo: Martins Fontes, 1992.

BARTHES, Roland. Aula. 6. ed. Trad. e posf. Leyla Perrone-Moisés. São Paulo: Cultrix, 1992.

BENVENISTE, Émile. Problemas de lingüística geral I. Campinas: Pontes, 1995.

BENVENISTE, Émile. Problemas de lingüística geral II. Campinas: Pontes, 1991.

CERTEAU, Michel de. A invenção do cotidiano: artes de fazer. 11. ed. Trad. Ephraim Ferreira Alves. Petrópolis: Vozes, 2005.

CONQUERGOOD, Dwight. Performance Studies: Interventions and Radical Research. In: BIAL, H. The Performance Studies Reader. London: Routledge, 2004.

CRUIKSHANK, Julie. Tradição oral e história oral: revendo algumas questões. In: AMADO, Janaína; FERREIRA, Marieta de Moraes. Usos e abusos da história oral. 4. ed. Rio de Janeiro: Editora FGV, 2001. 
FLORES, Valdir do Nascimento. Benveniste e o sintoma de linguagem: a enunciação do homem na língua. Letras, Santa Maria, n. 33, p. 99-118, jul.-dez. 2006a.

FLORES, Valdir do Nascimento. Entre o dizer e o mostrar: a transcrição como modalidade de enunciação. Organon, Porto Alegre, v. 20, n. 40/41, p. 61-75, jan.-dez. $2006 \mathrm{~b}$.

FONSECA, Claudia. Quando cada caso não é um caso - pesquisa etnográfica e educação. Revista Brasileira de Educação, n. 10, p. 58-78, jan.-fev.-mar.-abr. 1999.

FOUCAULT, Michel. A ordem do discurso. 14. ed. Trad. Laura Fraga de Almeida Sampaio. São Paulo: Loyola, 2006.

HALL, Stuart. Da diáspora: identidades e mediações culturais. Org. Liv Sovik. Trad. Adelaine La Guardia Resende, Ana Carolina Escosteguy, Cláudia Álvares, Francisco Rüdiger e Sayonara Amaral. Belo Horizonte: Editora UFMG; Brasília: Representação da UNESCO no Brasil, 2003.

MARTINS, José de Souza; ECKERT, Cornélia; NOVAES, Sylvia Caiuby (Org.). O imaginário e o poético nas Ciências Sociais. Bauru: EDUSC, 2005.

PESAVENTO, Sandra Jatahy. A pedra e o sonho: os caminhos do imaginário urbano. In: PESAVENTO, Sandra Jatahy. O imaginário da cidade. Porto Alegre: Ed. da Universidade/UFRGS, 1999.

RESENDE, Beatriz. Expressões da literatura brasileira no século XXI. Rio de Janeiro: Casa da Palavra; Biblioteca Nacional, 2008.

SANTOS, Boaventura de Sousa. A gramática do tempo: para uma nova cultura política. 2. ed. São Paulo: Cortez, 2006.

SANTOS, Milton. Técnica, espaço, tempo. 5. ed. São Paulo: Edusp, 2008.

TODOROV, Tzvetan. A literatura em perigo. Trad. Caio Meira. Rio de Janeiro: DIFEL, 2009.

VELHO, Gilberto. Projeto e metamorfose: antropologia das sociedades complexas. 2. ed. Rio de Janeiro: Jorge Zahar, 1999. 
VICH, Victor; ZAVALA, Virginia. Oralidad y poder: herramientas metodológicas. Buenos Aires: Norma, 2004.

ZUMTHOR, Paul. Introdução à poesia oral. Trad. Jerusa Pires Ferreira, Maria Lúcia Diniz Pochat e Maria Inês de Almeida. São Paulo: Hucitec, 1997.

ZUMTHOR, Paul. Escritura e nomadismo. Trad. Jerusa Pires Ferreira e Sônia Queiroz. São Paulo: Ateliê Editorial, 2005. 